\title{
Mechanism for increased insulin-stimulated glucose metabolism in adipocytes from 13-week-old obese Zucker rats
}

\author{
O. Ezaki \\ Division of Nutrition and Diseases, The National Institute of Nutrition, Tokyo, Japan
}

Summary. A study was made on the mechanism of increased glucose metabolism in enlarged adipocytes from 13-week-old obese Zucker rats showing hyperinsulinaemia and hyperglycaemia. Glucose metabolism was assessed by measuring $\mathrm{CO}_{2}$ production from glucose and the concentration of glucose transporters was estimated by immunoblotting. In comparing adipocytes from obese rats with those from lean rats, the basal rates of glucose oxidation at $0.02 \mathrm{mmol} / 1$ glucose increased 2.6-fold per unit cellular surface area and the transporters in the plasma membrane increased 1.4-fold per protein, while that in low-density microsome was $67 \%$ of the value in lean rats. The increase of glucose oxidation rates observed in basal cells from obese rats could be partly explained by translocation of the transporters from the intracellular site to the plasma membrane. In the presence of insulin, as the basal rates of glucose oxidation increased in obese rats, maximally insulin-stimulated oxidation increased 4-fold in lean rats and 1.7-fold in obese rats. Thus, the rates of insulin-stimulated oxidation on a per unit cellular surface area as well as the transporters on a per protein basis in the plasma membrane became almost similar in cells from both groups of rats. Since protein content per cell increased with cell enlargement, increased glucose metabolism per cell which was observed in adipocytes from the obese rats was mainly due to an increase of glucose transporters accompanied by a similar degree of cellular protein increase.

Key words: Adipose tissue, monosaccharide transport proteins, glucose oxidation, obesity in diabetes, Type 2 (non-insulin-dependent) diabetes, insulin resistance, Zucker rat.
Obese Zucker (fa/fa) rats have been used as an animal model of obesity, hyperinsulinaemia, and hyperlipoproteinaemia [1, 2]. Guerro-millo et al. have demonstrated that in the early stages of obesity in 30-day-old Zucker rats, the increase of insulin-stimulated glucose transport activity was due to an increase in the number of glucose transporters in the intracellular pool [3]. However, in animal models of obesity, the state of insulin resistance was gradually manifested, and older obese rats developed a state of insulin resistance $[4,5]$. Furthermore, it has been shown that 13- to 14-week-old rats have a significantly elevated basal glycaemia, whereas this was not the case in younger obese 6- to 7week-old rats [6]. In this study, to determine the contribution of glucose metabolism in adipocytes to either "so-called" insulin resistance or obesity, the effects of insulin on glucose metabolism in adipocytes from relatively aged 13-week-old fa/fa rats and their lean littermates were studied, and the distribution of glucose transporters was assessed by immunoblotting.

\section{Materials and methods}

\section{Materials}

D-[U- $\left.{ }^{14} \mathrm{C}\right]$-glucose (CFB. 96) and ${ }^{125}$ I-protein A (IM. 112) were purchased from Amersham (Buckinghamshire, UK); crude bovine serum albumin (Fraction V) from Armour (Kankakee, Ill, USA); crude bacterial collagenase (CLS) from Worthington (Freehold, NJ, USA); monocomponent porcine insulin from Novo (Copenhagen, Denmark); cytochalasin B from Aldrich Chemicals (Milwaukee, Wis, USA) and the other chemicals from Sigma (St.Louis, MO, USA). Polyclonal anti-human erythrocyte glucose transporter antibody whose characteristics have been described previously [7] was kindly provided by Dr. M. Kasahara (Teikyo University, Japan).

\section{Animals}

Genetically obese (fa/fa) and lean (FA/fa or FA/FA) female Zucker rats purchased from Tokyo Laboratory Animals Science Co. (Tokyo, Japan) were maintained at a constant temperature of $22^{\circ}$ with fixed artificial light cycle and were allowed free access to laboratory food 
and water. After fasting for $12 \mathrm{~h}$, blood was drawn from the inferior vena cava and the plasma used for determination of glucose [8] and immunoreactive insulin with rat insulin standards [9]. Glucose was measured by a determiner GL-R from Kyowa-medics (Tokyo, Japan).

\section{Preparation of isolated adipocytes}

Isolated adipocytes were prepared by collagenase method [10] with modifications. Perimetrial adipose tissue was obtained after administering $40 \mathrm{mg}$ pentobarbital (Nembutal, Abbott, North Chicago, Ill, USA). Adipose tissue ( $15-25 \mathrm{~g} / \mathrm{rat})$ obtained from one obese rat was cut into small pieces and then divided into four aliquots. However, adipose tissue (3-7 g/rat) from one lean rat was treated as one aliquot.

Each aliquot was incubated with $6 \mathrm{mg}$ collagenase in a $6 \mathrm{ml}$ buffer containing $119 \mathrm{mmol} / 1 \mathrm{NaCl}, 4.7 \mathrm{mmol} / 1 \mathrm{KCl}, 2.6 \mathrm{mmol} / 1 \mathrm{CaCl}_{2}$, $1.2 \mathrm{mmol} / 1 \mathrm{KH}_{2} \mathrm{PO}_{4}, 1.2 \mathrm{mmol} / 1 \mathrm{MgSO}_{4}, 32.3 \mathrm{mmol} / 1$ HEPES (4-2hydroxyethyl-1-piperazine ethanesulfonic acid) $\mathrm{pH} 7.4,20 \mathrm{mg} / \mathrm{ml}$ bovine serum albumin and $5 \mathrm{mmol} / 1 \mathrm{D}$-glucose or $2 \mathrm{mmol} / 1$ sodium pyruvate (buffer A) for $50 \mathrm{~min}$ at $37^{\circ} \mathrm{C}$. During incubation, the tube containing the adipose tissue was constantly agitated at 80 cycles per min and mixed gently every $5 \mathrm{~min}$ by hand. Each aliquot of cells was then filtered through several layers of gauze and transferred to another centrifuge tube. Into each centrifuge tube, $20 \mathrm{ml}$ of buffer $A$ was poured, and the tube was left standing for about $4 \mathrm{~min}$ without centrifugation until the adipocytes floated to the surface. The infranatant solution was then aspirated. This procedure was repeated four times to remove collagenase. This step was critical to obtain intact cells, as large adipocytes could be easily broken by repeated brief centrifugations.

\section{Subcellular fractionation of isolated adipocytes}

Subcellular fractionation of rat adipocytes was made using the method described by Kono et al. [11]. Each aliquot of cells was first incubated with $10 \mathrm{ml}$ buffer $\mathrm{A}$ for $30 \mathrm{~min}$ at $37^{\circ} \mathrm{C}$ and then with $5 \mathrm{nmol} / 1$ insulin or with buffer alone for $10 \mathrm{~min}$ in a polycarbonate Erlenmeyer flask. Homogenization was performed in a buffer containing $0.25 \mathrm{~mol} / 1$ sucrose, $1 \mathrm{mmol} / 1$ EDTA, and $10 \mathrm{mmol} / 1$ Tris$\mathrm{HCl}, \mathrm{pH} 7.5$ (buffer B). Each aliquot of cells was washed twice with $30 \mathrm{ml}$ buffer $\mathrm{B}$, suspended in $9 \mathrm{ml}$ buffer $\mathrm{B}$ at $20^{\circ} \mathrm{C}$, and homogenized with a glass homogenizer (Kontes, NJ, USA). The homogenate thus obtained was centrifuged at 2,200 $\mathrm{g}$ for $2 \mathrm{~min}$. The aqueous solution under the fat layer was withdrawn and centrifuged at $100,000 \mathrm{~g}$ for $60 \mathrm{~min}$. The pellet was designated as crude membrane fraction. This was suspended in buffer B and applied to the top of a $12 \mathrm{ml}$ linear sucrose gradient ( 15 to $32.5 \%$ (weight/weight)) containing buffer $\mathrm{C}$ $(1 \mathrm{mmol} / 1 \mathrm{EDTA}$ and $10 \mathrm{mmol} / 1$ Tris- $\mathrm{HCl}, \mathrm{pH} 7.5)$. After non-equilibrium centrifugation for $40 \mathrm{~min}$ at $35,000 \mathrm{rev} / \mathrm{min}$, the fractions containing 24-31\% sucrose were recovered as plasma membrane fraction and those containing 14-19\% sucrose as low-density microsome fraction. Vesicles in each fraction were washed with buffer $\mathrm{C}$ at $175,000 \mathrm{~g}$ for $90 \mathrm{~min}$, suspended in $100 \mu \mathrm{l}$ buffer $\mathrm{C}$ and stored at $-70^{\circ} \mathrm{C}$.

\section{Electrophoresis}

The pellet of the fractions was made soluble by boiling for $3 \mathrm{~min}$ in a solution containing $2.5 \%$ sodium dodecyl sulfate, $75 \mathrm{mmol} / 1$ dithiothreitol, $12.5 \%$ glycerol, $0.025 \%$ bromophenol blue and $12.5 \mathrm{mmol} / 1$ sodium phosphate, $\mathrm{pH}$ 7.0. Sodium dodecyl sulfate polyacrylamide gel electrophoresis was performed according to Laemmli [12] with $4 \%$ stacking gel and 9.5\% resolving gel. Immunoblotting of electrophoresis gels was performed as described previously [7, 13]. Briefly, proteins in gels were electrophoretically transferred to nitrocellulose sheets in a transfer buffer. The sheets were incubated successively with antibodies to glucose transporters and ${ }^{125}$ I-protein A. Autora-
Table 1. Glucose utilization activity at different glucose concentrations in intact adipocytes from lean and obese 13-week-old Zucker rats

\begin{tabular}{|c|c|c|c|c|}
\hline & Lean & & Obese & \\
\hline $\begin{array}{l}\text { a) } 5.0 \mathrm{mmol} / 1 \\
\text { Insulin }\end{array}$ & $\begin{array}{l}\text { glucose } \\
- \\
\end{array}$ & + & - & + \\
\hline $\begin{array}{l}\text { Per cell } \\
\left(\text { nmols } \cdot \min ^{-1}\right. \\
\left.\cdot 10^{6} \text { cells }^{-1}\right)\end{array}$ & $0.5 \pm 0.1$ & $1.7 \pm 0.2$ & $3.6 \pm 0.7^{\mathrm{a}}$ & $6.5 \pm 0.9^{b}$ \\
\hline $\begin{array}{l}\text { Per unit cellular } \\
\text { surface area } \\
\left(\left[\mathrm{nmols} \cdot \mathrm{min}^{-1}\right.\right. \\
\left.\left.-\mu \mathrm{m}^{-2}\right] \times 10^{12}\right) \\
\end{array}$ & $24 \pm 5$ & $81 \pm 9$ & $46 \pm 9$ & $83 \pm 11$ \\
\hline $\begin{array}{l}\text { b) } 0.02 \mathrm{mmol} / 1 \\
\text { Insulin }\end{array}$ & glucose & + & - & + \\
\hline $\begin{array}{l}\text { Per cell } \\
\left(\text { pmols } \cdot \min ^{-1}\right. \\
\left.\cdot 10^{6} \text { cells }^{-1}\right)\end{array}$ & $1.5 \pm 0.3$ & $6.0 \pm 0.7$ & $13.6 \pm 4.2^{\mathrm{a}}$ & $23.7 \pm 5.3^{b}$ \\
\hline $\begin{array}{l}\text { Per unit cellular } \\
\text { surface area } \\
\left(\left[\mathrm{pmols} \cdot \mathrm{min}^{-1}\right.\right. \\
\left.\left.\cdot \mu \mathrm{m}^{-2}\right] \times 10^{12}\right)\end{array}$ & $75 \pm 15$ & $299 \pm 35$ & $198 \pm 61^{\mathrm{a}}$ & $344 \pm 77$ \\
\hline
\end{tabular}

Glucose utilization activity was assessed from the production of $\mathrm{CO}_{2}$ from $\left[{ }^{14} \mathrm{C}\right]-\mathrm{D}$-glucose at two different glucose concentrations, $5 \mathrm{mmol} / 1$ and $0.02 \mathrm{mmol} / 1$ glucose, in the absence and presence of $5 \mathrm{nmol} / \mathrm{l}$ insulin. The data are expressed either per cell or per unit cellular surface area. Results are mean $\pm S E M$ of the individual mean values obtained in each of three experiments. Symbols "a" and "b" indicate difference of statistical significance by $t$-test between lean and obese rats at $p<0.05$ and $p<0.01$, respectively

diography was performed with Kodak XAR film (Rochester, NY, USA) at $-70^{\circ}$ for 2 days. To quantify the glucose transporters, pieces of nitrocellulose sheet containing the transporters were cut out and radioactivity counted in a gamma-counter. The radioactivity in individual spots corresponding to the transporters was proportional to the amount of protein applied (at least up to $50 \mu \mathrm{g}$ of low-density microsome fraction) in the same nitrocellulose sheet. To compare the amount of transporters in different nitrocellulose sheets, an internal standard of the transporters was applied in each gel electrophoresis.

\section{Glucose oxidation in adipocytes}

$\left[{ }^{14} \mathrm{C}\right]$ glucose carbon incorporated by adipocytes into $\mathrm{CO}_{2}$ was measured as described by Rodbell [10]. The cells were incubated either with $5 \mathrm{mmol} / 1\left[{ }^{14} \mathrm{C}\right]$-D-glucose or with $0.02 \mathrm{mmol} / 1\left[{ }^{14} \mathrm{C}\right]$-D-glucose plus $2 \mathrm{mmol} / 1$ sodium pyruvate (as a source of ATP) in the absence and presence of $5 \mathrm{nmol} / 1$ insulin for $30 \mathrm{~min}$ at $37^{\circ} \mathrm{C}$ in an Erlenmeyer flask $\left(0.5 \times 10^{6}\right.$ cells $/ 10 \mathrm{ml}$ buffer $\left.A\right)$. Radioactive carbon dioxide was trapped by adding $1 \mathrm{ml}$ of $4 \mathrm{~mol} / 1$ sulfuric acid to the incubation medium and the polyvial with filter paper impregnated with $0.5 \mathrm{ml}$ Hyamine hydroxide was suspended from the flask. After shaking for an additional hour, the polyvial was removed and radioactivity was counted in scintillation cocktails.

\section{Other assays}

Adipocyte cell number and size were measured using a cell-counting plate (Fuchs Rosental, Nitirin, Tokyo, Japan), $0.2 \mathrm{~mm}$ in depth, and eyepiece, assuming that the cells were spherical. The average diameter was obtained from 100 cells. The cell number of adipose tissue was es- 
timated by weighing undigested adipose tissue. Protein was assayed by Bradford's method [14]; 5'-nucleotidase by the method of Avruch and Wallach [15]; and UDP-galactose $\mathrm{N}$-acetylglucosamine galactosyltransferase by the method of Fleisher [16].

\section{Statistical analysis}

Data are shown as mean \pm standard error of the mean. Comparisons were made using the Student's $t$-test.

\section{Results}

The 13-week-old obese rats developed signs of Type 2 (non-insulin-dependent) diabetes such as hyperinsulinaemia and hyperglycaemia. Plasma insulin and glucose concentration were $2500 \pm 140 \mathrm{pmol} / 1$ and $10.8 \pm 1.2 \mathrm{mmol} / 1$ (mean $\pm \mathrm{SEM}, n=5$ ), respectively, in obese rats, while $69 \pm 7 \mathrm{pmol} / 1$, and $6.7 \pm 0.4 \mathrm{mmol} / 1$ in lean rats. Obese rats weighed $440 \pm 23 \mathrm{~g}$, while lean rats $233 \pm 11 \mathrm{~g}$. In adipose tissue from obese rats compared with that from the lean rats, the total number of cells from adipose tissue was almost similar, but cell enlargement was manifest. The mean of average diameter of adipocytes from individual obese rats was $146 \pm 4 \mu \mathrm{m}$, while $82 \pm 4 \mu \mathrm{m}$ from the lean rats.

Basal and maximally insulin-stimulated $\mathrm{CO}_{2}$ production from $\mathrm{D}-$ glucose is shown in both groups of cells in Table 1. As adipocytes from obese rats were easily ruptured by centrifugation, 3-O-methyl-D-glucose uptake could not be determined. When the cells were incubated with $5 \mathrm{mmol} / 1$ glucose at a physiological concentration, basal activity increased 1.9 -fold on a per unit cellular surface area, but insulin-stimulated activity remained constant. When the cells were incubated with $0.02 \mathrm{mmol} / 1$ glucose, a concentration in which the glucose oxidation activity reflected a step of glucose transport on plasma membrane [17], basal activity increased 2.6-fold, but insulin-stimulated activity remained constant. However, as the basal rates of oxidation were greater in obese rats, the rates of insulin-stimulated glucose oxidation were 4 -fold in lean rats and 1.7 -fold in obese rats.

The recovery of protein in the crude membrane fraction (= preparation before continuous sucrose density fraction) and that in subcellular fractions are presented in Table 2. Adipocytes from obese rats had more protein than that from the lean rats on a per cell basis. The percent recovery of both the plasma and low-density microsome proteins from crude membrane fractions were similar between cells from lean rats and those from obese rats. When expressed per unit cellular surface area, however, an almost identical protein concentration was recovered from each fraction.

The distribution of glucose transporters in subcellular fractions from 13-week-old lean and obese Zucker rats is shown in Figure 1 and Table 2. On a per $\mu \mathrm{g}$ protein basis, the amount of transporters in the plasma
Table 2. The distribution of protein and glucose transporters in subcellular fractions of basal and insulin-treated cells from 13-week-old lean and obese rats

\begin{tabular}{|c|c|c|c|c|}
\hline & Lean & & Obese & \\
\hline a) Protein & & & & \\
\hline & $\begin{array}{l}\text { Per cell } \\
\text { (pg/cell) }\end{array}$ & $\begin{array}{l}\text { Per unit cell } \\
\text { surface area } \\
\left(\mathrm{fg} / \mu \mathrm{m}^{2}\right)\end{array}$ & $\begin{array}{l}\text { Per cell } \\
\text { (pg/cell) }\end{array}$ & $\begin{array}{l}\text { Per unit cell } \\
\text { surface area } \\
\left(\mathrm{fg} / \mu \mathrm{m}^{2}\right)\end{array}$ \\
\hline$M$ & $158 \pm 22$ & $7.7 \pm 1.1$ & $521 \pm 51^{b}$ & $7.1 \pm 0.7$ \\
\hline PM & $13.5 \pm 2.0$ & $0.7=$ & $47.4 \pm 3.3^{\mathrm{b}}$ & 0.0 \\
\hline LM & $7.9 \pm 1.0$ & $0.4 \pm 0.1$ & $31.4 \pm 5.0^{b}$ & $0.4 \pm 0.1$ \\
\hline Gl & transporters & & & \\
\hline & $\begin{array}{l}\text { Per cell } \\
\left(\mathrm{cpm} / 7 \times 10^{5}\right)\end{array}$ & $\begin{array}{l}\text { Per protein } \\
(\mathrm{cpm} / \mu \mathrm{g})\end{array}$ & $\begin{array}{l}\text { Per cell } \\
\left(\mathrm{cpm} / 7 \times 10^{5}\right)\end{array}$ & $\begin{array}{l}\text { Per protein } \\
(\mathrm{cpm} / \mu \mathrm{g})\end{array}$ \\
\hline Insulin & & & & \\
\hline $\mathrm{PM} \quad-$ & $80 \pm 16$ & $8.5 \pm 1.7$ & $410 \pm 19^{b}$ & $12.3 \pm 0.6$ \\
\hline+ & $226 \pm 19$ & $23.8 \pm 2.0$ & $701 \pm 27^{\mathrm{b}}$ & $21.1 \pm 0.8$ \\
\hline $\mathrm{LM} \quad-$ & $204 \pm 18$ & $36.9 \pm 3.3$ & $547 \pm 42^{\mathrm{b}}$ & $24.9 \pm 1.9^{\mathrm{a}}$ \\
\hline+ & $62 \pm 6$ & $11.2 \pm 1.1$ & $182 \pm 32^{\mathrm{a}}$ & $8.3 \pm 1.5$ \\
\hline
\end{tabular}

The amount of proteins in subcellular fractions were measured by a dye-binding method; the transporters were by immunoblotting. The protein content was obtained from the averaged values of each fraction from basal and insulin-treated cells. The data are expressed per cell or per unit cell surface area or per $\mu \mathrm{g}$ protein. The symbol " $M$ " indicates membrane fraction; PM, plasma membrane fraction; and LM, low-density microsome fraction. Results are mean \pm SEM of the individual mean values obtained in each of three experiments. Symbols "a" and "b" indicate difference of statistical significance by $t$-test between lean and obese rats at $p<0.05$ and $p<0.01$, respectively

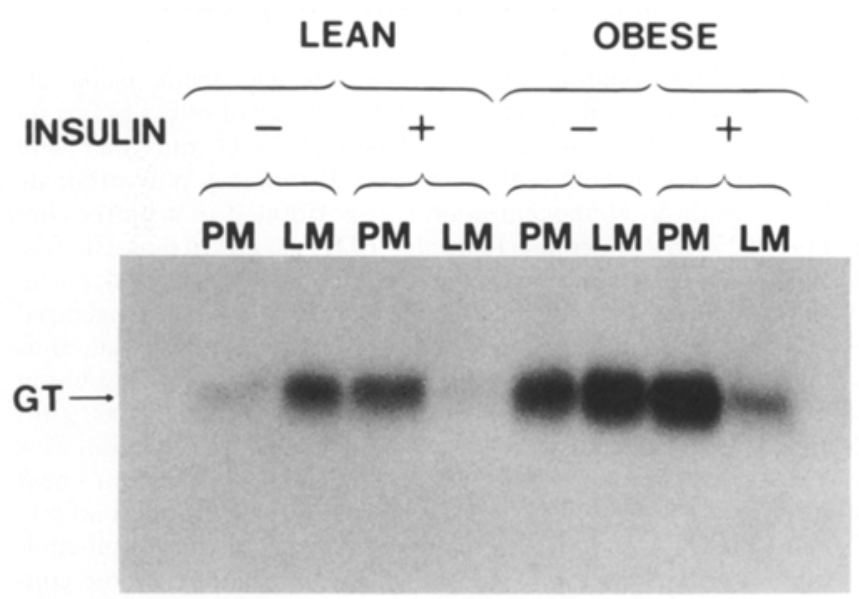

Fig. 1. A representative autoradiogram of glucose transporters in plasma membrane (PM) and low-density microsome (LM) fractions of adipocytes from 13-week-old lean and obese Zucker rats. Membrane fractions were prepared from the same number of isolated adipocytes incubated either in the absence or presence of $5 \mathrm{nmol} / 1 \mathrm{in}$ sulin. The glucose transporters of each fraction from $7 \times 10^{5}$ cells were detected by immunoblotting, followed by autoradiography

membrane fraction of basal cells from obese rats increased 1.4-fold compared to lean rats, while the transporters in plasma membrane fraction from insulintreated cells from obese rats were almost the same as those from lean rats. In the presence of insulin, the amount of transporters in the plasma membrane increased in both groups by the translocation mechanism 
Table 3. Marker enzyme-specific activities in subcellular fractions in cells from 13-week-old lean and obese rats

\begin{tabular}{|c|c|c|c|}
\hline & & Lean & Obese \\
\hline $\begin{array}{l}5 \text {-nucleotidase } \\
\left(\text { nmols } \cdot \min ^{-1} \cdot \text { mg protein }^{-1}\right)\end{array}$ & $\begin{array}{l}\text { PM } \\
\text { LM }\end{array}$ & $\begin{array}{r}20.0 \pm 2.9 \\
6.2 \pm 1.0\end{array}$ & $\begin{array}{r}19.9 \pm 2.3 \\
7.8 \pm 0.5\end{array}$ \\
\hline $\begin{array}{l}\text { Galactosyltransferase } \\
\text { (pmols } \cdot \min ^{-1} \cdot \text { mg protein }^{-1} \text { ) }\end{array}$ & $\begin{array}{l}\text { PM } \\
\text { LM }\end{array}$ & $\begin{array}{r}80 \pm 9 \\
330 \pm 24\end{array}$ & $\begin{array}{r}83 \pm 6 \\
299 \pm 14\end{array}$ \\
\hline
\end{tabular}

The enzyme activities obtained from the averaged values of each fraction from basal and insulin-treated cells were measured. Results are mean \pm SEM of the individual means values obtained in each of three experiments. The symbol "PM" indicates plasma membrane fraction; and LM, low-density microsome fraction

$[18,19] ; 70 \%$ and $67 \%$ of the transporters in the lowdensity microsome fraction of basal cells from the lean and obese rats, respectively, translocated to the plasma membrane.

Shown in Table 3 are the relative enrichments of marker enzymes, 5'-nucleotidase activity for the plasma membrane and galactosyltransferase activity for Golgi apparatus in each fraction. In general, each fraction from obese rats was not associated with significant changes in either marker enzyme distribution.

\section{Discussion}

The cell surface area enlarged 3.2-fold in cells from obese rats associated with a parallel increase of protein content per cell in each fraction, but the concentration of protein on the plasma membrane remained constant. In the absence of insulin, the amount of glucose transporters in the plasma membrane from obese rats increașed 1.4-fold on a protein basis. In the low-density microsome fraction, the amount of the transporters from obese rats on a per protein basis, decreased to $67 \%$ of that from lean rats. These data suggested that the translocation of transporters from the intracellular site to the plasma membrane occurred in basal cells from obese rats. A higher basal concentration of glucose transporters in the plasma membrane fraction of cells from obese rather than from lean rats cannot be ruled out as a consequence of increased contamination from glucose transporter-containing vesicles in low density microsome fraction, but less likely because of similar distribution patterns of the galactosyltransferase activity in each fraction of cells from both groups of rats; and because of a parallel increase in glucose oxidation activity per unit cellular surface area in intact cells. However, glucose oxidation activity per unit surface area at $0.02 \mathrm{mmol} / 1$ glucose was 2.7 -fold greater in cells from obese rats. This higher ratio than that of translocated transporters in the plasma membrane $(=1.4$-fold $)$ indicated that other mechanism(s) might be involved. The increased intrinsic activity of transporters from obese rats may be one of the mechanisms. Several recent studies with rat adipocytes have suggested modulation of intrinsic activity of the transporter [20, 21]. Also, the existence of another type of transporter which was not detected by this antibody but was translocated to the plasma membrane may be another mechanism. Since a family of structurally related glucose transporters was identified in different cell types [22, 23], this antibody against erythrocyte-type glucose transporter might react with other forms. To clarify this question, the transport activity remaining in the supernatant after immunoprecipitation of transporter-containing vesicles with this antibody was assessed with reconstitution. After immunoprecipitation with Pansorbin coated with this antibody, $60 \%$ of transport activity remained in the supernatant compared to that with non-immune IgG, whereas the fact that $24 \%$ of the antibody-reactive transporter remained in the supernatant suggested that this antibody recognized one of the major insulin-responsive transporters and that another type of transporter might exist [24]. However, the major factor contributing to increased basal activity per cell from obese rats is an increase of the protein content associated with the transporters. The finding that most of the transporters in animals with age-related obesity are in the plasma membrane [25] suggests the importance of increased transporters in plasma membrane under the basal state in developing obesity. Since a higher rate of glucose oxidation in obese rats compared to lean rats was observed at both $0.02 \mathrm{mmol} / 1$ and $5 \mathrm{mmol} / 1$ glucose, the data suggesting post-transport steps also increased in obese rats or the transport step was still rate-limiting even at $5 \mathrm{mmol} / 1$ glucose. As insulin treatment in adipocytes translocated a similar ratio of transporters in low-density microsome fractions of the cells from both lean and obese rats to the plasma membrane, the vesicle containing the glucose transporters in both groups has a similar ability to translocate to the plasma membrane. The increase of insulin-stimulated glucose oxidation activity per cell from obese rats can be explained by both translocation of transporters and increase in the amount of transporters with increase of protein content. In 30-day-old obese rats, both increase of protein per cell and increase of transporters per protein resulted in increase of glucose transport activity from obese rats [3]. These data indicated that concentration of transporters per protein gradually decreased with aging. Under the opposite metabolic condition, the insulin-depleted state, Karnieli et al. reported decrease of cell size, protein content per cell, and 3-O-methyl-D-glucose transport activity per cell in diabetic rats [26]. These data indicate that insulin itself stimulates an increased number of glucose transporters as one of its anabolic effects on the overall increase of protein synthesis.

In spite of marked hyperinsulinaemia and modest hyperglycaemia in 13-week-old obese Zucker rats, the present data clearly indicate that both basal and insulinstimulated glucose metabolism are increased, compared to the cells from lean littermates. Previously, Czech et al. [27] and Cushman et al. [28] have also shown an increased glucose transport activity and glu- 
cose oxidation in adipocytes from 10- and 20-week-old Zucker rats. These data are in contrast to the idea that hyperinsulinaemia and obesity are characterized by insulin resistance, and indicate that adipose tissue of Zucker rats is not a suitable model for obesity-mediated insulin resistance. However, the increased content of glucose transporters persists at least in 13-week-old obese rats suggesting that the increasing number of glucose transporters may be one of the causes of the development and maintenance of obesity. Hyperglycaemia during the hyperinsulinaemic state at this stage may be explained by increased hepatic glucose production or insulin resistance of muscles.

Acknowledgement. This work was supported by a grant from the Uehara Memorial Foundation of Japan.

\section{References}

1. Zucker LM, Zucker TF (1961) Fatty, a new mutation in the rat. $\mathbf{J}$ Hered 52: 275-278

2. Bray GA (1977) The Zucker-fatty rat: a review. Fed Proc 36: 148-153

3. Guerre-Millo M, Lavau M, Horne JS, Wardzala LJ (1985) Proposed mechanism for increased insulin-mediated glucose transport in adipose cells from young, obese Zucker rats. J Biol Chem 260: 2197-2201

4. Pénicaud L, Rohner-Jeanrenaud F, Jeanrenaud B (1986) In vivo metabolic changes as studied longitudinally after ventromedial hypothalamic lesions. Am J Physiol 250: E662-668

5. Terrtaz J, Assimacopoulos-Jeannet F, Jeanrenaud B (1986) Severe hepatic and peripheral insulin resistance as evidenced by euglycemic clamps in genetically obese $(\mathrm{fa} / \mathrm{fa})$ rats. Endocrinology 118: 674-678

6. Ionescu E, Sauter JF, Jeanrenaud B (1985) Abnormal oral glucose tolerance in genetically obese $(\mathrm{fa} / \mathrm{fa})$ rats. Am J Physiol 248: E500-506

7. Ezaki O, Kasuga M, Akanuma Y, Takata K, Hirano H, FujitaYamaguchi Y, Kasahara M (1986) Recycling of the glucose transporter, the insulin receptor, and insulin in rat adipocytes. Effect of acidtropic agents. J Biol Chem 261:3295-3305

8. Banauch VD, Brümmer W, Ebeling $\mathrm{H}$, Metz $\mathrm{H}$, Rindfrey $\mathrm{H}$, Lang H, Leybold K, Rick W (1975) A glucose dehydrogenase for the determination of glucose concentrations in body fluids. $Z$ Klin Chem Klin Biochem 13: 101-107

9. Kuzuya T, Samols E (1964) The plasma insulin "inhibitor" and immunoprecipitation assay. Metabolism 13: 493-495

10. Rodbell M (1964) Metabolism of isolated fat cells. J Biol Chem 239: $375-380$

11. Kono T, Robinson FW, Blevins TL, Ezaki O (1982) Evidence that translocation of the glucose transport activity is the major mechanism of insulin action on glucose transport in fat cells. J Biol Chem 257: 10942-10947

12. Laemmli UK (1970) Cleavage of structure proteins during the assembly of the head of bacteriophage T4. Nature 227:680-685

13. Towbin H, Staehelin T, Gordon J (1979) Electrophoretic transfer of proteins from polyacrylamide gels to nitrocellulose sheets:
Procedure and some applications. Proc Natl Acad Sci USA 76: 4350-4354

14. Bradford MM (1976) A rapid and sensitive method for the quantitation of microgram quantities of protein utilizing the principle of protein-dye binding. Anal Biochem 72:248-254

15. Avruch J, Wallach DFH (1971) Preparation and properties of plasma membrane and endoplastic reticulum fragments from isolated fat cells. Biochim Biophys Acta 233: 334-347

16. Fleisher B (1974) Isolation and characterization of Golgi apparatus and membranes from rat liver. Methods Enzymol 31: 180-191

17. Foley JE, Cushman SW, Salans LB (1980) Intracellular glucose concentration in small and large rat adipose cells. Am $\mathbf{J}$ Physiol 238: E180-185

18. Cushman SW, Wardzala LJ (1980) Potential mechanism of insulin action on glucose transport in the isolated rat adipose cell. Apparent translocation of intracellular glucose transport systems to the plasma membrane. J Biol Chem 255: 4758-4762

19. Suzuki K, Kono T (1980) Evidence that insulin causes translocation of glucose transport activity to the plasma membrane from an intracellular storage site. Proc Natl Acad Sci USA 77:2542-2545

20. Joost HJ, Weber TM, Cushman SW, Simpson IA (1986) Insulinstimulated glucose transport in rat adipose cells. J Biol Chem 261: 10033-10036

21. Baly DL, Horuk R (1987) Dissociation of insulin-stimulated glucose transport from the translocation of glucose carriers in rat adipose cells. J Biol Chem 262: 21-26

22. Thorens B, Sarkar HK, Kaback HR, Lodish HF (1988) Cloning and functional expression in bacteria of a novel glucose transporter present in liver, intestine, kidney, and -pancreatic islet cells. Cell 55: $281-290$

23. Kayano T, Fukumoto H, Eddy RL, Fan YS, Byers MG, Shows TB, Bell GI (1988) Evidence for a family of human glucose transporter-like proteins. J Biol Chem 263: 15245-15248

24. Ezaki O, Bono N, Itakura H, Kasahara M (1989) Co-localization of a glucose transporter and the insulin receptor in microsomes of insulin-treated rat adipocytes. Biochem Biophys Res Commun (in press)

25. Hissin PJ, Foley JE, Wardzala LJ, Karnieli E， Simpson IA, Salans LB, Cushman SW (1982) Mechanism of insulin-resistant glucose transport activity in the enlarged adipose cell of the aged, obese rat. J Clin Invest 70:780-790

26. Karnieli E, Hissin PJ, Simpson IA, Salans LB, Cushman SW (1981) A possible mechanism of insulin resistance in the rat adipose cell in streptozotocin-induced diabetes mellitus. J Clin Invest 68: 811-814

27. Czech MP, Richardson DK, Becker SG, Walters CG, Gitomer W, Heinrich J (1978) Insulin response in skeletal muscle and fat cells of the genetically obese Zucker rat. Metabolism 27: 1967-1981

28. Cushman SW, Zarnowski MJ, Franzusoff AJ, Salans LB (1978) Alterations in glucose metabolism and its stimulation by insulin in isolated adipose cells during the development of genetic obesity in the Zucker fatty rat. Metabolism 27: 1930-1940

Received: 3 October 1988

and in revised form: 28 February 1989

Dr. O. Ezaki

The National Institute of Nutrition

1-23-1, Toyama

Tokyo 162

Japan 